DOI https://doi.org/10.18551/rjoas.2020-09.13

\title{
THE ROLE OF FINANCIAL INSTITUTIONS (BANKS) IN THE DEVELOPMENT OF UMM IN WEST OF NUSA TENGGARA PROVINCE, INDONESIA
}

\author{
Asrin* \\ Postgraduate Program, University of Udayana, Denpasar, Indonesia
}
Setiawina Djinar, Budhi M. Kembar Sri, Yasa Murjana, Lecturers
University of Udayana, Denpasar, Indonesia

*E-mail: asrinugr@gmail.com

\begin{abstract}
This research aims to analyze: (1) the effect of credit received on Business Micro Small Medium income; (2) the influence of the competence of human resources (HR) on the income; (3) the influence of entrepreneurship orientation on Business Micro Small Medium. income; (4) the effect of credit received on the welfare of Business Micro Small Medium employees; (5) the influence of competence of human resources (HR) on employee welfare; (6) the influence of entrepreneurial orientation on employee welfare; (7) the indirect effect of received credit, the competence of human resources (HR) and the influence of entrepreneurial orientation on employee welfare through the income of Business Micro Small Medium. This research is a quantitative research conducted in West Nusa Tenggara Province in 10 districts / cities with a sample size of 110 respondents. Data analysis was performed using the SEM-PLS method. The results of research and data analysis indicate that: (1) credit received has no and significant effect on welfare; (2) the competence of human resources has a significant and significant effect on employee welfare; (3) entrepreneurial orientation has a significant and significant effect on the income of Business Micro Small Medium; (4) credit received has no significant effect on employee welfare; (5) the competence of human resources has a significant and significant effect on employee welfare; (6) entrepreneurial orientation has no and significant effect on employee welfare; (7) Business Micro Small Medium income has a significant and significant effect on employee welfare; (8) Business Micro Small Medium income (Y1) is unable to mediate positively and significantly the indirect effect of credit received (X1) on employee welfare (Y2); (9) Business Micro Small Medium income (Y1) is unable to mediate positively and significantly the indirect effect of human resources (X3) on employee welfare (Y2); (10) Business Micro Small Medium income (Y1) is able to positively and significantly mediate the indirect effect of entrepreneurial orientation (X2) on employee welfare (Y2).
\end{abstract}

\section{KEY WORDS}

Employee welfare, credit received, entrepreneurial orientation, income, human resources.

One of the components that support national development is a bank financial institution or intermediary institution which has the function of collecting funds from the public and channeling them back to the community in the form of credit and other forms.

Financial business is carried out by companies engaged in the financial sector or intermediary institutions that have the function and effort to collect funds from the public and channel them back to the community in the form of credit and other forms. Fahmi (2014) states that a financial institution is a business entity whose wealth is primarily in the form of financial assets or claims such as stocks, bonds, compared to real assets such as buildings, equipment and raw materials. According to Hasibuan (2008: 2), state-owned banks are financial institutions, money creators, fund collectors and credit providers, executor of payment traffic, monetary stability, and a dynamist of economic growth As a financial institution, banks are also important institutions in supporting the economic activities of a nation. Indonesia in this case is a country that has a very large area consisting of 34 
Provinces and 514 City Regencies in it and spreads from Sabang to Merauke, one of which is West Nusa Tenggara, the capital is Mataram, which consists of 10 Regencies / Cities, 116 Districts, and 1141 Villages / Wards, and a population of 4,955,578 people (NTB in numbers, 2018)

These types of financial institutions have the same role, namely to support the development and performance of MSME for the people of West Nusa Tenggara (NTB). Fry (1988: 301) states that in almost all countries, bank regulation has two objectives, namely protecting depositors and increasing the role of monetary supervision.

In many developing countries, there is a third objective of financial institutions, namely credit allocation based on priority plans. It was only in October 1988 that the government established a banking deregulation policy which confirmed that the types of banks in Indonesia were Commercial Banks and Rural Banks (BPR)

Basically, commercial banks and rural banks are financial institutions that were formed and established to serve the needs of banking services in general, especially for the business community Business Micro Small Medium in Indonesia. Currently the development of financial institutions is so fast and rapid and their existence is in various areas ranging from urban to rural areas. In particular, the business world in NTB has felt the impact of the development of credit extended to Business Micro Small Medium from year to year, which has continued to increase from both commercial banks and rural banks.

Of the total number of Business Micro Small Medium that exist, most are in the agricultural sector compared to other Business Micro Small Medium Nearly $50 \%$ of the existing Business Micro Small Medium are agricultural sector Business Micro Small Medium while the trade sector is around $29 \%$. While the remaining $21 \%$ is engaged in the service sector, construction and others. Although the number of Business Micro Small Medium in the agricultural sector is far more than the trade sector, in terms of GDP creation, the Business Micro Small Medium in the trade sector is more than the agricultural sector. This condition shows that the trade sector Business Micro Small Medium are able to create greater added value than Business Micro Small Medium in the agricultural sector.

Various initiatives have been attempted by the government through the State Ministry for Cooperatives and Small and Medium Enterprises so that more individuals and groups are willing to pursue the world of entrepreneurship in the form of establishing Business Micro Small Medium Although the support of the Indonesian government is very large to make Business Micro Small Medium successful and developing, it does not mean that it is without obstacles. The agenda for accelerating economic recovery and strengthening the foundation for sustainable and equitable development is realized through the development of a democratic economic system based on justice while still paying attention to optimal utilization of human resources (HR) and the preservation of independent entrepreneurs.

The existence of micro, small and medium enterprises Business Micro Small Medium in Indonesia is well recognized as one of the most important priorities in national economic development. This is because in addition to this, it is a business that is able to survive when Indonesia's economic conditions are experiencing such a great crisis and is also able to accommodate a large workforce. Another impact that is no less important is that Business Micro Small Medium are able to reduce the problem of social inequality, as well as alleviate poverty, and are an important pillar for the people's economy. The existence of a planned Business Micro Small Medium development policy will provide maximum benefits to regional economic development such as job creation, provision of goods and services, equitable development, and technology transfer. Independent entrepreneurship is needed by individuals who are ready to fight entrepreneurship, because entrepreneurship must be sensitive to conscience and have a sharp business instinct to penetrate a competitive market share. Bawsir, 1997). The characteristics of entrepreneurs Business Micro Small Medium can affect the development of their business, the need for success, the desire to take risks, self-confidence and a strong desire to do business, in addition to the characteristics of entrepreneurship, venture capital is absolutely necessary in carrying out Business Micro Small Medium business activities. Problems that often occur in Business Micro Small Medium in order to increase their income are the low level of technology possessed by 
Business Micro Small Medium and the difficulty of obtaining capital. Initial capital is needed to establish and run a business. Initial capital is a fund required for investment capital and working capital. Nazir (2010), states that one of the elements that affect income is the factor of production in which the variable is capital. To obtain maximum income, initial capital is needed for the company's operational activities, capital is an important factor that must be prepared and available before starting to carry out Business Micro Small Medium business activities.

The size of the capital will affect business development in achieving business goals, namely income. According to Riyanto (2001), business capital can be obtained from two sources, namely own capital and external capital (loans). This loan capital is synonymous with credit obtained from program credit and others organized by financial institutions in the form of banks and non-banks. The difficulty of accessing sources of financing makes Business Micro Small Medium owners tend to use their own limited capital to run their business rather than applying for loans to banks or other financial institutions. Whereas loans or debts given by banks or other financial institutions can motivate owners to promote their business, this is due to the burden on business owners to repay loans (Kasmir, 2006: 89).

Apart from entrepreneurial characteristics in the form of venture capital, there is no less importance is the existence and existence of human resources owned by Business Micro Small Medium. HR is a fundamental characteristic of a person related to work that can be developed through various education and training, to create quality human resources for the achievement of effectiveness and efficiency, as well as high productivity so that the expected goal of income can be achieved maximally.

There are several considerations that need to be taken to increase Business Micro Small Medium. income, including the absorption of labor (HR) by Business Micro Small Medium. The greater the income received, the higher the business potential to finance expenses and business activities. Problems that often occur in Business Micro Small Medium in order to increase their income are the low level of technology possessed by Business Micro Small Medium and the difficulty of obtaining capital. Initial capital is needed to set up and run a business in addition to investment capital and working capital.

Capital and debt are among the financial aspects that are the main obstacles for Business Micro Small Medium to increase their income, because of the difficulty of obtaining financing sources. Other financial aspects that can increase Business Micro Small Medium income are the assets used by Business Micro Small Medium for business operations and improving business performance. Assets have economic benefits indicated by the service potential or utility attached to them, namely a scarce power or capacity that can be utilized by business entities in their efforts to generate income through economic activities, namely consumption, production and exchange. (Suwardjono, 2010: 301). Business Micro Small Medium have been proven to make significant positive contributions to efforts to overcome economic and social problems in Indonesia. Small businesses are companies or industries that have a workforce of 5 to 19 people, while Medium Enterprises are companies or industries that have a workforce of 20 to 99 people (Tambunan 2009). Business Micro Small Medium has an important role in providing employment opportunities. This also applies to SME in NTB

Business Micro Small Medium have also shown significant achievements in Indonesia's economic development. The growth of Business Micro Small Medium itself is quite fast, higher than the growth of large-scale businesses. In terms of exports, Business Micro Small Medium were able to record a value of $20 \%$ of total non-oil and gas exports. These are all assumptions that in the future Business Micro Small Medium will be able to make a greater contribution to the development of the Indonesian economy in general. (LIPI, 2010). To improve the competitiveness of Micro, Small and Medium Enterprises , Business Micro Small Medium the government continues to strive to direct the management of Business Micro Small Medium One of the accelerations carried out by the government through the Ministry of Cooperatives and SMEs at this time is the movement "One Million Businesses Up Grade". This movement will be formulated in the 2015 - 2019 National Medium Term Development Plan (RPJMN). ready to face the Asean Economic Community (MEA) which is currently 
underway. With good management of Business Micro Small Medium it is hoped that they will be able to be competitive in facing MEA competition not only among domestic Business Micro Small Medium but also more widely to the Asean community. Thus, the goal of employee welfare can be realized.

The welfare of workers or employees is one form of handling the workforce and is one of the goals that both private companies and government agencies are trying to achieve. In principle, employee welfare does not only lie in the level of income (wages) provided by the organization or company, but other factors also play an important role, the attention of employers to health insurance, work equipment, work environment, training and work skills. . Thus, good employee work performance will contribute to benefits or can encourage the progress of the company in a better direction. In addition, promotion for employees with good achievements will be beneficial for the employees themselves, where the promotion will improve the position or position of an employee in the company. Many factors affect the performance of small companies, Business Micro Small Medium, including the influence of internal and external factors (Wang and Wong, 2004). Declaring the success of Business Micro Small Medium depends on the ability to manage these two factors through analysis of environmental factors and the formation and implementation of business strategies.

With regard to external factors that can affect the performance of Business Micro Small Medium related to environmental aspects, Wilkinson (2002) states that small and micro enterprises will grow if the regulatory / policy environment supports, the macroeconomic environment is well managed, stable, and predictable; reliable and easily accessible information, and the social environment encourage and reward the success of the venture.

The utilization of credit by entrepreneurs is still low, because the credit received is not all used as business capital, so that when the use of credit received does not separate between business capital and consumption for daily needs, therefore when business capital is running low the entrepreneur immediately takes another credit from the financial institution to increase business capital.

\section{METHODS OF RESEARCH}

The type of research used in this research is associative research, which researchers use to construct relationships between social situations or domains with one another (Sugiyono, 2016). This research was conducted in all Business Micro Small Medium in West Nusa Tenggara (NTB) Province, as described above. This is to determine the role of financial institutions in NTB and their influence on the development and performance of Business Micro Small Medium. The technique used in determining the sample cluster technique. This cluster sampling technique selects samples not based on individuals, but rather based on groups, regions, or groups of subjects who naturally gather together. Cluster techniques are often used by researchers in fields whose areas may be large. One of the methods used to determine the number of samples in this study is to use the Slovin formula.

This study uses structural equation modeling (SEM) with the PLS (Partial Least Square) 3.0 alternative, which is an analysis method that is widely used by researchers today because it can be applied to all data scales with small or large sample sizes. The purpose of using PLS as a measuring tool to predict the variables of the role of financial institutions (banks) on the development and performance of MSME.

\section{RESULTS AND DISCUSSION}

The loading factor value of the KD1 to KD4 indicators on the received credit construct has a value greater than 0.6. This means that the indicators KD1 to KD4 can measure the credit constructs received in this study. On the other hand, the loading factor value of the KD5 indicator does not meet the validity requirements of the received credit construct because it has a value smaller than 0.6 , namely 0.510 . This indicates that the KD5 indicator does not correlate with the credit construct received so that this indicator is dropped from the model. 


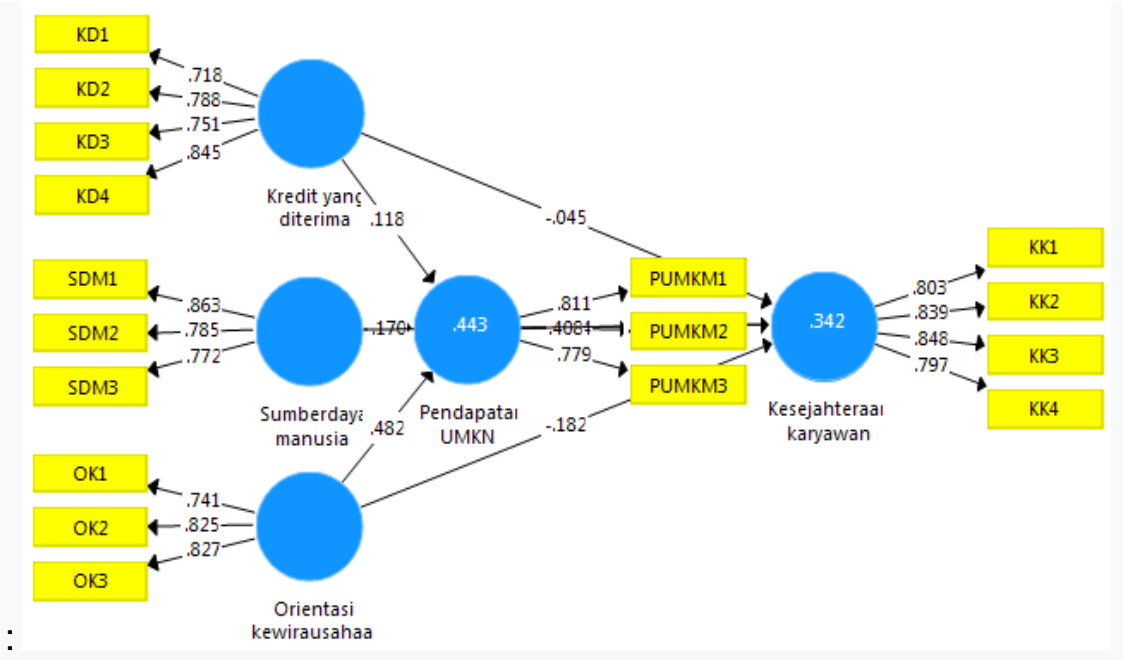

Figure 1 - Results of Re-Estimate Model

The results of re-estimating the model after removing the KD5 indicator made the loading factor value of the indicators KD1 0.718 , KD2 0.788 , KD3 0.751 , and KD4 0.845 . The credit construct indicators received have met the convergent validity because the loading factor value is already above 0.6. The loading factor value is also supported by the Average Variance Extracted (AVE) value which is greater than 0.5. The AVE value from the PLS Algorithm analysis is presented in Table 1 below:

Table 1 - AVE value from the PLS Algorithm analysis

\begin{tabular}{llll}
\hline Variable & AVE & Terms & Information \\
Credit received & 0,605 & 0,5 & Valid \\
\hline
\end{tabular}

The next test of the credit constructs received is through discriminant validity testing seen from the cross loading between the indicators and the constructs. If the construct correlation with the indicator is greater than the correlation of the indicator with other constructs, the construct predicts the indicators in their block better than the indicators in other blocks, so that it meets the requirements for discriminant validity (Ghozali and Hengky, 2015: 39). The results of the discriminant validity test are presented in Table 2.

Table 2 - Cross Loading

\begin{tabular}{|c|c|c|c|c|c|}
\hline Variable & KK & $\mathrm{KD}$ & OK & PUMKN & SDM \\
\hline KD1 & .177 & .718 & .366 & .226 & .388 \\
\hline KD2 & .077 & .788 & .296 & .284 & .284 \\
\hline KD3 & .072 & .751 & .255 & .265 & .302 \\
\hline KD4 & .286 & .845 & .281 & .360 & .365 \\
\hline KK1 & .803 & .209 & .373 & .487 & .413 \\
\hline KK2 & .839 & .089 & .252 & .367 & .399 \\
\hline KK3 & .848 & .203 & .274 & .367 & .420 \\
\hline KK4 & .797 & .211 & .194 & .426 & .392 \\
\hline OK1 & .153 & .435 & .741 & .370 & .539 \\
\hline OK2 & .212 & .336 & .825 & .612 & .501 \\
\hline OK3 & .399 & .193 & .827 & .506 & .539 \\
\hline PUMKM1 & .342 & .285 & .575 & .811 & .518 \\
\hline PUMKM2 & .431 & .353 & .482 & .804 & .420 \\
\hline PUMKM3 & .438 & .259 & .468 & .779 & .339 \\
\hline SDM1 & .504 & .508 & .506 & .488 & .863 \\
\hline SDM2 & .370 & .234 & .581 & .455 & .785 \\
\hline SDM3 & .279 & .255 & .499 & 324 & .772 \\
\hline
\end{tabular}

It is known that the cross loading between indicators KD1 has a value of $0.718, K D 2$, 0.788 , KD3 0.751 and KD4 0.845 with the accepted credit construct where this value is greater than 0.70 . A cross loading value greater than 0.70 indicates that the latent construct 
predicts indicators in their block better than indicators in other blocks. Thus it can be concluded that the indicators KD1, KD2, KD3, and KD4 have met the criteria for discriminant validity or the indicators are declared valid. Furthermore, the reliability test was carried out by looking at the composite reliability on the PLS Algorithm results. The rule of thumb that is commonly used to assess construct reliability according to Ghozali and Hengky (2015: 75) is that the composite reliability value must be greater than 0.70 for confirmatory research. The credit construct received is declared reliable because it obtains a composite reliability value of 0.786 , this value is greater than 0.70 . Following are the results of the PLS Algorithm analysis to see the value of composite reliability.

Table 3 - Value of Composite Reliability

\begin{tabular}{llll}
\hline & Cronbach's Alpha & Value & Result \\
Employee Welfare & 0,840 & $>0,7$ & Reliable \\
Credit Received & 0,786 & $>0,7$ & Reliable \\
Entrepreneurial Orientation & 0,722 & $>0,7$ & Reliable \\
UMKM Income & 0,716 & $>0,7$ & Reliable \\
Human Resources & 0,738 & $>0,7$ & Reliable \\
\hline
\end{tabular}

R-square is used to explain the effect of certain exogenous constructs on endogenous constructs whether it has a substantive effect. R-square values of $0.67,0.33$ and 0.19 can be concluded that the model is strong, moderate and weak (Ghozali and Hengky, 2015: 81). The R-square value of the analysis using the bootstrap resampling method at a significance level of 5 percent is presented in Table 4.

Table 4 - R-square value

\begin{tabular}{ll}
\hline $\mathrm{n} / \mathrm{n}$ & $R$ Square \\
Employee welfare & 0.342 \\
UMKM income & 0.443 \\
\hline
\end{tabular}

Based on Table 4, it can be seen that the R-square value of the relationship between the variable credit received, human resources, and entrepreneurial orientation to the income of Business Micro Small Medium is 0.443 . The R-square value of 0.443 or $44.3 \%$ is classified as a moderate influence model. This shows that the Business Micro Small Medium income construct can be explained by the variables of credit received, human resources, and entrepreneurial orientation of only $44.3 \%$, the remaining $56.7 \%$ is explained by other variables outside the model built in this study.

Table 5 - Effect Size Values

\begin{tabular}{lll}
\hline Variable & UMKM Income & Employee Welfare \\
Credit received & 0,020 & 0,002 \\
Human Resources & 0,028 & 0,132 \\
Entrepreneurial orientation & 0,236 & 0,023 \\
UMKM income & - & 0,149 \\
\hline
\end{tabular}

The effect size value consists of $0.02 ; 0.15$; and 0.35 . This value illustrates that the predictors of latent variables have small, medium, and large effects at the structural level. Based on Table 5.9, it can be seen that credit received and human resources each have a contribution of 0.020 and 0.028 , which means that these variables are in the weak category and indicate that the contribution of credit received and human resources to the income of Business Micro Small Medium has little effect. Meanwhile, the entrepreneurial orientation variable has a contribution of 0.236 which means it is included in the middle category.

For the variable credit received and entrepreneurial orientation, each has a contribution of 0.002 and 0.023 , which means that the variable is in the weak category and indicates that the contribution of credit received and entrepreneurial orientation towards human resources has a small effect, while the human resources and income of Business Micro Small Medium 
variables. has a contribution of 0.132 and 0.149 which means it is included in the middle category.

The Q2 predictive relevance value is used to measure how well the observation value is generated by the model and also its parameter estimation or to know the predictive capability of the blindfolding procedure (Ghozali and Latan 2015: 81). The value of Q2> 0 indicates that the model has predictive relevance, while the value of $Q 2<0$ indicates that the model lacks predictive relevance. The predictive relevance Q2 value is obtained from the following calculations:

$$
\mathrm{Q} 2=1-(1-\mathrm{R} 2)=0.342
$$

Based on the results of the above calculations, the Q2 value for the predictive relevance construct of employee welfare is 0.342 or the Q2 value is predictive relevance> 0 , which means that this research model has predictive relevance.

$$
\mathrm{Q} 2=1-(1-\mathrm{R} 2)=0.443
$$

Based on the results of the above calculations, the Q2 value for the predictive relevance of MSME income construct is 0.443 or the Q2 value is predictive relevance> 0 , which means that this research model has predictive relevance. The inner model test is also done by looking at the significance value to see the influence between variables. For the significant value of hypothesis support, a comparison of the T-table and T-Statistics values can be used in the estimation results for path coefficient (path coefficient value). If T-statistics is greater than T-table, it means that the hypothesis is supported. The significant value used for the two-tailed hypothesis with a confidence level of 95 percent (alpha 5 percent) is 1.982 . In addition, to test the hypothesis, it can be done by analyzing the $p$ value compared to the errors specified in this study, namely one-tailed (two tailed) test with alpha $5 \%(0.05)$. If $p$ values $<0.05$ means that the hypothesis is accepted but if $p$ values $>0.05$ means that the hypothesis is rejected. The results of the path coefficient analysis are presented in Table 6 below:

Table 6 - Results of Path Coefficient Analysis

\begin{tabular}{llllll}
\hline Variable & Original sample & T Statistic & P Values & Value & Result \\
KD -> KK & -.045 & .367 & .714 & Not significant & The Hypothesis Is Rejected \\
KD -> PUMKN & .118 & 1.152 & .250 & Not significant & The Hypothesis Is Rejected \\
OK -> KK & -.182 & 1.219 & .223 & Not significant & The Hypothesis Is Rejected \\
OK -> PUMKN & .482 & 5.031 & .000 & Not significant & The Hypothesis Is Rejected \\
PUMKN -> KK & .419 & 4.203 & .000 & Not significant & The Hypothesis Is Rejected \\
SDM -> KK & .408 & 2.483 & .013 & Not significant & The Hypothesis Is Rejected \\
SDM -> PUMKN & .170 & 1.743 & .082 & Not significant & The Hypothesis Is Rejected \\
\hline
\end{tabular}

The first hypothesis states that the smaller the credit received, the smaller the employee welfare. Table 5.10 shows that the t-statistic value for the effect of credit received on employee welfare is 0.367 . This value is smaller than the table value at the 5 percent significance level, namely 1.982 , so it can be concluded that the hypothesis is rejected. The $p$ value for the effect of credit received on employee welfare is 0.714 greater than the alpha value of 0.05 . This means that the relationship between credit received and employee welfare is not significant, so the hypothesis is rejected. The coefficient value of the credit measure parameter received on employee welfare is -0.045 in a negative direction. This means that credit received has a negative impact on employee welfare.

The second hypothesis states that the smaller the credit received, the smaller the Business Micro Small Medium income. Table 5.10 shows that the t-statistic value for the effect of credit received on Business Micro Small Medium income is 1.152 . This value is smaller than the $t$ table value at the 5 percent significance level, namely 1.982 , so it can be concluded that the hypothesis is rejected. The $p$ value for the effect of credit received on Business Micro Small Medium income is 0.250 greater than the alpha value of 0.05 . This 
means that the relationship between credit received and Business Micro Small Medium income is not significant, so the hypothesis is rejected. The coefficient value of the credit measure parameter received on employee welfare is 0.118 in a positive direction. This means that the credit received does not have an impact on MSME income

The third hypothesis states that the smaller the entrepreneurial orientation, the smaller the employee welfare. Table 5.10 shows that the t-statistic value for the effect of credit received on employee welfare is 1.219 . This value is smaller than the table value at the 5 percent significance level, namely 1.982 , so it can be concluded that the hypothesis is rejected. The $p$ value for the effect of entrepreneurial orientation on employee welfare is 0.223 greater than the alpha value of 0.05 . This means that the relationship between entrepreneurial orientation and employee welfare is not significant, so the hypothesis is rejected. The coefficient value of the credit measure parameter received on employee welfare is -0.182 with a negative direction. This means that entrepreneurial-oriented loans have a negative impact on employee welfare.

The fourth hypothesis states that the greater the entrepreneurial orientation, the greater the income of Business Micro Small Medium Table 5.10 shows that the t-statistic value for the effect of entrepreneurial orientation on Business Micro Small Medium income is 5.031. This value is greater than the t table value at the 5 percent significance level, namely 1.982 , so it can be concluded that the hypothesis is accepted. The $p$ value for the influence of entrepreneurship orientation on Business Micro Small Medium income is 0,000 smaller than the alpha value of 0.05 . This means that the relationship between entrepreneurial orientation and Business Micro Small Medium income is significant, so the hypothesis is accepted. The coefficient value of the credit measure parameter received on employee welfare is 0.482 with a positive direction. This means that entrepreneurial orientation has an impact on Business Micro Small Medium income.

The fifth hypothesis states that the greater the income of Business Micro Small Medium the greater the welfare of employees. Table 5.10 shows that the t-statistic value for the effect of credit received on employee welfare is 4.203. This value is greater than the table value at the 5 percent significance level, namely 1.982 , so it can be rejected that it is accepted. The $P$ value for the effect of Business Micro Small Medium income on employee welfare is 0,000 smaller than the alpha value of 0.05 . This means that the relationship between Business Micro Small Medium income and employee welfare is significant, so it is accepted. The coefficient value of the credit measure parameter received on employee welfare is 0.419 in a positive direction. This means that Business Micro Small Medium income has a positive impact on employee welfare.

The sixth hypothesis states that the greater the competence of human resources, the greater the welfare of employees. Table 5.10 shows that the t-statistic value for the effect of credit received on employee welfare is 2.483 . This value is greater than the table value at the 5 percent significance level, namely 1.982 , so it can be concluded that the hypothesis is accepted. The $p$ value for the effect of human resource competence on employee welfare is 0.013 smaller than the alpha value of 0.05 . This means that the relationship between human resource competence and employee welfare is significant, so the hypothesis is accepted. The coefficient value of the received credit measure parameter on employee welfare is 0.408 with a positive direction. This means that human resource competence has a positive impact on employee welfare.

The seventh hypothesis states that the smaller the competence of human resources, the smaller the income of Business Micro Small Medium. Table 5.10 shows that the t-statistic value for the effect of credit received on Business Micro Small Medium income is 1.743. This value is smaller than the t table value at the 5 percent significance level, namely 1.982 , so it can be concluded that the hypothesis is rejected. The $p$ value for the competence of human resources received on Business Micro Small Medium income is 0.082, greater than the alpha value of 0.05 . This means that the relationship between human resource competence and income of Business Micro Small Medium is not significant, so the hypothesis is rejected. The value of the parameter coefficient of the measure of credit received on employee welfare is 
0.170 in a positive direction. This means that the credit received does not have an impact on Business Micro Small Medium income

In testing the following hypothesis, the role of the Business Micro Small Medium income variable $(\mathrm{Y} 1)$ will be examined as a mediator on the indirect effect of received credit (X1), human resources (X2), and entrepreneurial orientation (X3) on employee welfare (Y2). Testing the indirect effect hypothesis in this study using the Sobel test, which can be explained the results of the analysis in Table 7 below.

Table 7 - Indirect Effect Testing Results

\begin{tabular}{llll}
\hline Variable & Original sample & T Statistic & P Values \\
KD -> PUMKN -> KK & .050 & .922 & .357 \\
OK -> PUMKN -> KK & .202 & 2.703 & .007 \\
SDM - PUMKN -> KK & .071 & 1.552 & .121 \\
\hline
\end{tabular}

Business Micro Small Medium income $(\mathrm{Y} 1)$ is not able to mediate positively and significantly the indirect effect of credit received (X1) on employee welfare (Y2). These results are shown from the Sobel test that tcount: 0.922 is smaller than ttable: 1.982 . Based on the results of this test, hypothesis $8(\mathrm{H} 8)$ cannot be proven empirically. Based on these results it can be stated, that the smaller the income of Business Micro Small Medium from the credit received, the less it will have an impact on employee welfare.

Business Micro Small Medium income (Y1) is able to positively and significantly mediate the indirect effect of entrepreneurial orientation (X2) on employee welfare (Y2). These results are shown from the Sobel test that tcount: 2.708 is greater than t table: 1.982 . Based on the results of this test, hypothesis 9 (H9) can be proven empirically. Based on these results it can be stated that the higher the income of Business Micro Small Medium from entrepreneurial orientation, the higher the employee welfare.

The third hypothesis states that the smaller the entrepreneurial orientation, the smaller the employee welfare. Table 5.10 shows that the t-statistic value for the effect of credit received on employee welfare is 1.219. This value is smaller than the table value at the 5 percent significance level, namely 1.982 , so it can be rejected that it is rejected. The $P$ value for the effect of entrepreneurial orientation on employee welfare is 0.223 greater than the alpha value of 0.05 . This means that the relationship between the entrepreneurial orientation of employee welfare is not significant, so the hypothesis is rejected. The coefficient value of the credit measure parameter received on employee welfare is -0.182 with a negative direction. This means that entrepreneurial-oriented loans have a negative impact on employee welfare.

The fourth hypothesis states that the greater the entrepreneurial orientation, the greater the income of Business Micro Small Medium. Table 5.10 shows that the t-statistic value for the effect of entrepreneurial orientation on Business Micro Small Medium income is 5.031. This value is greater than the t table value at the 5 percent significance level, namely 1.982 , so it can be concluded that the hypothesis is accepted. The $p$ value for the influence of entrepreneurship orientation on Business Micro Small Medium income is 0,000 smaller than the alpha value of 0.05 . This means that the relationship between entrepreneurial orientation and Business Micro Small Medium income is significant, so the hypothesis is accepted. The coefficient value of the credit measure parameter received on employee welfare is 0.482 with a positive direction. This means that entrepreneurial orientation has an impact on Business Micro Small Medium income

The fifth hypothesis states that the greater the income of Business Micro Small Medium the greater the welfare of employees. Table 5.10 shows that the t-statistic value for the effect of credit received on employee welfare is 4.203 . This value is greater than the table value at the 5 percent significance level, namely 1.982 , so it can be concluded that the hypothesis is accepted. The $p$ value for the effect of Business Micro Small Medium income on employee welfare is 0,000 smaller than the alpha value of 0.05 . This means that the relationship between Business Micro Small Medium income and employee welfare is significant, so the hypothesis is accepted. The coefficient value of the received credit measure parameter on 
employee welfare is 0.419 with a positive direction. This means that Business Micro Small Medium income has a positive impact on employee welfare.

The sixth hypothesis states that the greater the competence of human resources, the greater the welfare of employees. Table 5.10 shows that the t-statistic value for the effect of credit received on employee welfare is 2.483 . This value is greater than the table value at the 5 percent significance level, namely 1.982 , so it can be concluded that the hypothesis is accepted. The $p$ value for the effect of human resource competence on employee welfare is 0.013 smaller than the alpha value of 0.05 . This means that the relationship between human resource competence and employee welfare is significant, so the hypothesis is accepted. The value of the parameter coefficient of the measure of credit received on employee welfare is 0.408 in a positive direction. This means that human resource competence has a positive impact on employee welfare.

The seventh hypothesis states that the smaller the competence of human resources, the smaller the income of Business Micro Small Medium Table 5.10 shows that the t-statistic value for the effect of credit received on Business Micro Small Medium income is 1.743. This value is smaller than the t table value at the 5 percent significance level, namely 1.982 , so it can be concluded that the hypothesis is rejected. The $p$ value for the competence of human resources received on Business Micro Small Medium income is 0.082 , greater than the alpha value of 0.05 . This means that the relationship between human resource competence and income of Business Micro Small Medium is not significant, so the hypothesis is rejected. The value of the parameter coefficient of the measure of credit received on employee welfare is 0.170 in a positive direction. This means that the credit received does not have an impact on Business Micro Small Medium income.

In testing the following hypothesis, the role of the Business Micro Small Medium income variable $(\mathrm{Y} 1)$ will be examined as a mediator on the indirect effect of received credit (X1), human resources (X2), and entrepreneurial orientation (X3) on employee welfare (Y2). Testing the indirect effect hypothesis in this study using the Sobel test, which can be explained the results of the analysis in Table 7 below.

Table 7 - Indirect Effect Testing Results

\begin{tabular}{llll}
\hline Variable & Original sample & T Statistic & P Values \\
KD -> PUMKN -> KK & .050 & .922 & .357 \\
OK -> PUMKN -> KK & .202 & 2.703 & .007 \\
SDM -> PUMKN -> KK & .071 & 1.552 & .121 \\
\hline
\end{tabular}

Business Micro Small Medium income $(\mathrm{Y} 1)$ is not able to mediate positively and significantly the indirect effect of credit received (X1) on employee welfare (Y2). These results are shown from the Sobel test that tcount: 0.922 is smaller than ttable: 1.982 . Based on the results of this test, hypothesis $8(\mathrm{H} 8)$ cannot be proven empirically. Based on these results it can be stated that the smaller the income of Business Micro Small Medium from the credit received, the less it will have an impact on employee welfare.

Business Micro Small Medium income $(\mathrm{Y} 1)$ is able to positively and significantly mediate the indirect effect of entrepreneurial orientation (X2) on employee welfare (Y2). These results are shown from the Sobel test that tcount: 2.708 is greater than t table: 1.982 . Based on the results of this test, hypothesis 9 (H9) can be proven empirically. Based on these results it can be stated that the higher the income of Business Micro Small Medium from entrepreneurial orientation, the higher the employee welfare.

Business Micro Small Medium income (Y1) is not able to positively and significantly mediate the indirect effect of human resources (X3) on employee welfare (Y2). These results are shown from the Sobel test that tcount: 1.552 is smaller than t table: 1.982 . Based on the results of this test, hypothesis $9(\mathrm{H} 9)$ cannot be proven empirically. Based on these results, it can be stated that the smaller the income of Business Micro Small Medium from human resources, the less it will have an impact on employee welfare.

This examination of the mediation model is carried out as an effort to provide information on the level of intervention of the mediating variable, whether it is full mediation 
or partial mediation. The results of the examination of this mediation model refer to Hair et al. (2010). An examination of the mediation model can be presented as follows:

The mediation of Business Micro Small Medium income (Y1) on the indirect effect of credit received $(\mathrm{X} 1)$ on employee welfare $(\mathrm{Y} 2)$ is partial mediation. This finding is a sign that Business Micro Small Medium income $(\mathrm{Y} 1)$ is not a key mediator on the indirect effect of received credit (X1) on employee welfare (Y2). Other information that can be conveyed is that the credit received $(\mathrm{X} 1)$ does not play a direct role in improving employee welfare (Y2) than in increasing Business Micro Small Medium income (Y1) first. It is proven that the path coefficient of direct effect of credit received on employee welfare is dominant $(-0.045)$ compared to the path coefficient of indirect effect through mediation of Business Micro Small Medium income (0.002).

The mediation of Business Micro Small Medium income (Y1) on the indirect effect of human resources (X2) on employee welfare (Y2) is partial mediation. This finding is a sign that Business Micro Small Medium Business Micro Small Medium income (Y1) is not a key mediator on the indirect effect of human resources (X2) on welfare employee (Y2). Other information that can be conveyed is that human resources (X2) have a direct role in improving employee welfare (Y2) rather than increasing Business Micro Small Medium income (Y1) first. This is evidenced by the dominant direct effect path coefficient of human resources on employee welfare (0.408) compared to the indirect effect path coefficient through the mediation of Business Micro Small Medium income (0.166).

Table 8 - Direct, Indirect, and Total Effects

\begin{tabular}{llll}
\hline Variable & Direct Influence & Indirect Influence & Total Effect \\
KD -> PUMKN -> KK & $-0,045$ & 0,002 & 0,051 \\
& & $0,118 * 0,419$ & 0,166 \\
OK -> PUMKN -> KK & $-0,182$ & $0,482 * 0,419$ & 0,367 \\
& & 0,033 & 0,104 \\
\hline
\end{tabular}

The mediation of Business Micro Small Medium income $(\mathrm{Y} 1)$ on the indirect effect of entrepreneurial orientation (X3) on employee welfare (Y2) is partial mediation. employee (Y2). Other information that can be conveyed, entrepreneurial orientation (X3) has a direct role in improving employee welfare (Y2) rather than increasing Business Micro Small Medium income (Y1) first. This is evidenced by the dominant direct effect path coefficient of entrepreneurial orientation on employee welfare $(-0.182)$ compared to the indirect effect path coefficient through the mediation of Business Micro Small Medium income (0.033).

This research differs from the decision theory to establish various rules of requirements until the guarantee for each debtor who applies for a loan to the lending institution (Bank) is aimed at protecting against the existence of the funds that have been given. The position of guarantee in providing credit is aimed at minimizing the risk that will be received in the future (future risk) (Fahmi, 2014). This research is also in line with the research of Halloh (2001) who conducted a study in East Java, Bali and NTB which found that the low level of credit distribution was caused by several things, namely: non-current bills, human resources, and bad credit, caused by internal and external factors, inadequate character and credit analysis. The low quality of the debt portfolio, the value of collateral (collateral) and the minimum provision for possible loan losses are also factors that cause the low ability of financial institutions to extend credit to Business Micro Small Medium and the public. Furthermore, Halloh also said that there were two reasons why credit disbursement by financial institutions was low due to the supervision of loans and high interest rates on bank loans. This research is in line with (PAPI) (2001), the definition of credit according to the Indonesian Banking Accounting Guidelines as the provision of money or an equivalent bill, based on a loanborrowing agreement or agreement between a bank and another party that requires the borrower (debtor) to pay off the debt after a certain period of time with the amount of interest, reward or profit sharing. 
The findings of this study are that although financial institutions provide credit to entrepreneurs with various supports including characteristics, capital, guarantees, and abilities, they will not provide much profit with loans because each small and micro entrepreneur only relies on the capital received from banks. and the benefits obtained are greater for financial institutions for credit installments.

This study is not in line with the concept of Yati (2009) which states that competence is a part of the personality that is deep and inherent in a person with predictable behavior in various jobs and job assignments. In performance management, competence plays a greater role in the dimensions of individual behavior in adjusting a job properly. Existing performance appraisals need to be equipped with skills and knowledge, namely communication, teamwork, leadership and analytical decision making.

Research conducted by Salman (2009) shows that income is influenced by working capital, labor, number of hours worked, and the level of education of small businesses in Langkat Regency. The results of research by Rosetyadi and Fitrie (2013) show that the variables of initial capital, length of business, and working hours have an effect on the amount of income of kiosk traders in Bintoro Demak Market. The dominant variable that affects the amount of income is the initial capital variable, while the variable that has the smallest influence is the working hour variable.

The findings of this study are that the competence of human resources in Law No. 13 of 2003 concerning manpower states that there are four employees for types of work, namely once completed work, seasonal work, work from a new business, new products or new activities, as well as work that is irregular in nature (freelance workers) (Budiadji, 2008), so that the income of Business Micro Small Medium will not increase because of the type of work that has been determined by Law No. 13 of 2003.

This research is in line with the concept of Utami (2012: 4) which states that "Entrepreneurial orientation is a process, practice, and decision-making activity that leads to new entry. Entrepreneurial orientation emerges from a strategic choice perspective which states that the chances of a new entry being successful are highly dependent on the performance objectives.

\section{CONCLUSION}

The results of the study are in line with the research of Dwiyanti, et al, (2014), which analyzed the existence of initial capital, debt, assets and entrepreneurial orientation which consisted of innovation, proactivity, and risk taking to determine the income of Business Micro Small Medium in the service and trade sectors in Jember Regency. Sampling was done using purposive sampling and convenience sampling methods, so that 42 respondents were obtained as the sample. Multiple linear regression analysis is used as a method of analysis in this article. The results obtained are the variables of assets, innovation and proactivity in determining the income of Business Micro Small Medium. The variables that cannot determine the income of Business Micro Small Medium are initial capital, debt, and risk taking. Assets and pro-activity have a positive effect on income, while the innovation variable has a negative effect on income. This research is also in line with the theoretical concept. Strategic Management Concept in small organizations such as Business Micro Small Medium should be a strategic entrepreneurial concept. The strategic concept of entrepreneurship has 3 elements including: intuitive, creative and rational. Strategic is a stepping process by an entrepreneur in a company, presenting his views on how the organization should develop and what quantitative targets he already knows. This leads to a vision statement that outlines how Business Micro Small Medium should develop and goals that must be met within a certain time.

\section{REFERENCES}

1. Agus,S. 2004. Artikel Membangun Fundamental Perbankan yang Kuat. Penerbit: Harian Media Indonesia, Jakarta. 
2. Anantanyu, Sapja. 2011. Kelembagaan Petani: Peran dan Strategi Pengembangan Kapasitasnya. SEPA, Vol. 7(2): 102-109.

3. Anggraini D, Nasution SH. 2013. Peranan kredit usaha rakyat (KUR) bagi pengembangan UMKM di Kota Medan (studi kasus Bank BRI). Jurnal Ekonomi dan Keuangan 1(3): 105116.

4. Ariff, Faisal, dan Rekan, 1996. Bank, Strategi dan Operasional, Cetakan Pertama, Penerbit PT. Eresco, Bandung.

5. Bank Indonesia, (2005). Surat Edaran No.7/85/INTERN tentang Pedoman Pelaksanaan Bantua Teknis dalam Rangka Pengembangan Usaha Mikro, Kecil, dan Menengah.

6. Bank Indonesia, Statistik Keuangan Daerah Provinsi Nusa Tenggara Barat Januari 2017.

7. Colter, J. M,1984, "Masalah perkreditan dalam pembangunan Pertanian" dalam Faesal Kasryno, Prospek Pembangunan Ekonomi Pedesaan Indonesia, Yayasanm Obor Indonesia, Jakarta.

8. Chen, Cheng-Nan, 2007, The Relation among Social Capital, Entrepreneurial Orientation, Organizational Resources and Entrepreneurial Performance for New Ventures, Contemporary Management Research, National Cheng Kung University.

9. Daymon, Christine, dan Immy Holloway. 2008. Metode-metode Riset Kualitatif dalam Public Relations dan marketing Communications. Bentang Pustaka: Yogyakarta.

10. Dendawijaya, Lukman, Ir, MM, 2005, Manajemen Perbankan, Penerbit Ghalia Indonesia,Bogor, Indonesia Galeri UKM. 2011 Kriteria Usaha Mikro Kecil dan Menengah (Online),(http://galeriukm.web.id/news/kriteria-usaha-mikro-kecil-dan-menengah-umkm, diakses 1 oktober 2011.

11. Ghozali, I., (2006), Aplikasi Analisis Multivariate dengan Program SPSS. Edisi 3. Badan Penerbit Universitas Diponegoro Semarang.

12. Hanafie, Rita. 2010. Pengantar Ekonomi Pertanian. CV. Andi Offset: Yogyakarta.

13. Herri SE, MBA, PhD, dan kawan-kawan, 2006, Studi Peningkatan Peran BPR dalam Pembiayaan Usaha Mikro Kecil (UMK) di Sumatra Barat.

14. Ida Bgs. Eka Artika. 2012, Peran Lembaga Keuangan dalam Mendorong Perkembangan Umkm dan Fungsi Bank Perkreditan Rakyat (Bpr) dalam Perkembangan Dunia Usaha Di Nusa Tenggara Barat, Univ.

15. Mahasaraswati Mataram Ikatan Akuntan Indonesia, 2002. Standar Akuntansi Keuangan, Penerbit Salemba Empat, Jakarta Inpres No. 10 Tahun 1999 tentang Pemberdayaan Usaha Menengah.

16. Irham Fahmi, 2014. Pengantar Perbankan Teori dan Aflikasi, Penerbit Alfabeta, Bandung

17. Kasmir, 2003, Manajemen Perbankan, PT. Raja Grafindo Persada, Jakarta.

18. (2012), ank dan Lembaga Keuangan Lainnya, Fajar Interpratama Offset, Jakarta.

19. Keppres No. 127 Tahun 2001 tentang Bidang/Jenis Usaha Yang Dicadangkan Untuk Usaha Kecil dan Bidang/Jenis Usaha Yang Terbuka Untuk Usaha Menengah atau Besar Dengan Syarat Kemitraan.

20. Meydianawathi, Luh Gede (2007) "Analisis Perilaku Penawaran Kredit Perbankan terhadap Sektor UMKM di Indonesia (2002-2006)", Buletin Studi Ekonomi Vol.12. No 2 Tahun 2007.

21. Muttaqien, Arif, 2008, "Knowledge Management" untuk KUKM, Portal Pengembangan KUKM Indonesia.

22. Najib, 2006, Peningkatan Kinerja Bisnis Usaha Kecil Menengah dengan Pengembangan Orientasi Pasar, Jurnal Manajemen Publikasi Penelitian dan Review Vol 1 No. 2.

23. Nugroho, Bramasto. 2010. Pembangunan Kelembagaan Pinjaman Dana Bergulir Hutan Rakyat. JMHT, Vol. 16(3): 118-125.

24. Parera, J.D, 2004. Bank Indonesia, Bank Sentral Republik Indonesia, Suatu Pengantar, Penerbit Pusat pendidikan dan Studi Kebanksentralan (PPSK) Ban kIndonesia, Jakarta.

25. Peraturan pendukung yaitu Kitab Undang- Undang Hukum Perdata dan Kitab Undangundang Hukum Dagang.

26. Peraturan Pemerintah No. 17 Tahun 1999 tentang Badan Penyehatan Perbankan Nasional.

27. No. 25 Tahun 1999 tentang Pencabutan Izin Usaha, Pembubaran dan Likuidasi. 
28. Papulova, Emilia \& Zuzana Papulova, 2006, Competitive Strategy And Competitive Strategi Advantages Of Small And Midsezed Manufacturing Enterprises In Slovakia, Bratislava, Slovak Republic, Comenius University.

29. Pujilistiyani, Angelina Yuli, 2008, Charecteristic Of Manajerial Careers, Journal Review.

30. Rahman, Fazlur. Islam, $2^{\text {nd }}$ Edition. Chicago-USA \& KONDON (UK): The University of Chicago Press. 1989.

31. Rahmana, Arief. 2008. Usaha Kecil dan Menengah (UKM), Informasi Terdepan tentang Usaha Kecil Menengah, (online), (http://infoukm.wordpress. com, diakses 1 oktober 2011.

32. Sudaryanto. 2011. The Need for ICT-Education for Manager or Agribusinessman to Increasing Farm Income : Study of Factor Influences on Computer Adoption in East Java Farm Agribusiness. International Journal of Education and Development, JEDICT, Vol 7 No 1 halm. 56-6.

33. Sudaryanto dan Hanim, Anifatul. 2002. Evaluasi kesiapan UKM Menyongsong Pasar Bebas Asean (AFTA) : Analisis Perspektif dan Tinjauan Teoritis. Jurnal Ekonomi Akuntansi dan Manajemen, Vol 1 No 2, Desember 2002.

34. Sudirman, I Wayan, 2013. Manajemen Perbankan Menuju Bankir Konvensional yang Profesional Edisi Pertama, Penerbit, Kencana Perdana Media Group, Jakarta.

35. Susilo, Y.Sri, Sigit Triandaru, dan A.Totok Budi Santoso, 2000. Bank dan Lembaga Keuangan Lainnya, Cetakan Pertama, Penerbit-Salemba Empat, Jakarta.

36. Sutopo, Wahyudi (2005) Hubungan Antara Lembaga Keuangan Mikro dan Kontribusi Usaha Kecil dalam Pengentasan Kemiskinan, Manajemen Usahawan Indonesia, No.01, XXX, Januari, hal 3-1.

37. Suyanto, M. 2005. Artikel, Aplikasi IT untuk UKM Menghadapi Persaingan Global. Yogyakart.

38. Slamat, Dahlan. 1995. Manajemen Bank Umum. Edisi Kesatu. Jakarta: Erlangga.

39. Stephen P. Robbins, 2003. Perilaku Organisasi, terjemahan resmi dari edisi bahasa Inggris. Penerbit PT. Indeks kelompok Gramedia, Jakarta.

40. Tambunan Mangara, (2002). Apakah Usaha Menengah Mengalami Stagnasi. PaperStaff, Center for Economic and Social Studies (CESS). 